\title{
Free Time
}

\author{
E. YVETTE STOGNER \\ Louisiana State University (United States)
}

The Louisiana Department of Education dictates all public school districts follow its comprehensive curricula, designed to prepare students for standardized tests administered to all public school students in grades 4-11. These curricula provide teachers with activities and grade level expectations (GLE's) that should be covered and time schedules that should be followed. These comprehensive curricula have become a hotly debated topic since their inception, because many educators feel instructional creativity and personal teaching styles are being stifled. Teachers can no longer teach how and what they want to teach; they must follow the mandated guidelines. While the GLE's are a main focus of these curricula, their pacing schedules can be adjusted slightly by the local school districts. In order to better ready students for the standardized tests, my local school district encourages teachers to complete the curricula before the tests are administered during the spring semester. One particular year, the local school district's pacing chart labeled what remains of the school year after testing (about six weeks) as "free time." This brief article is a reflection of my teaching experience during free time.

\section{Free time $=$ Nothing}

For me, the term "free time" carries negative connotations. It reminds me of the early days of my teaching career when I would finish teaching a lesson, and the students would pack their bags early, sit, and talk. Nothing would happen in these moments-no teaching accomplished, no learning occurred, no objectives met, no goals reached. Free = nothing. I remember feeling regret at having lost this precious instructional time. Free time is not a pleasurable time, either. It is a time when the volume can become loud, the students can become unruly, the classroom can become messy, and the teacher can become frustrated. I have, since those early days of teaching, learned how to avoid this dreaded free time altogether. Over-planning insures that every second of instructional 
time can be used more effectively. Isn't that what our local school systems want? Don't they insist that every possible second be spent preparing students for the state mandated standardized tests? I thought I had everything under control, but I was wrong.

In May of 2006, the principal informed me my teaching schedule was changed. I would no longer teach in my classroom located at the high school end of our campus. I was moved to another classroom on the opposite end of campus where the junior high classes are taught. I would no longer teach ninth, eleventh, and twelfth grade English; I was forced to teach seventh and eighth grade reading and English. Having now to examine thoroughly a new comprehensive curriculum and local school system mandated timeline, while feeling an enormous amount of anger, frustration, and anxiety about this new life experience (not to mention I was still suffering from postpartum depression, weaning a baby, discovering I was newly pregnant, taking two postgraduate courses and in the process of moving homes), I was horrified to find those terrible words that I had purposely avoided, laughing in my face . . free time. The local school system timeline indicated the state comprehensive curriculum must be taught in completion before the standardized tests, iLEAP and LEAP, are administered. On the local school system timeline, the weeks after testing week were literally labeled "free time." In all my previous years of teaching, I had never seen these words on the high school timelines; what did it mean? Certainly there was some sort of mistake. Was this some sort of joke? I could only think of chaos and confusion-of misbehavior and migraines. This change was turning into a more difficult adjustment than I could have imagined.

I reflected on the connotations I had always linked to this phrase or even the idea of free. When something is free, it almost always is so because someone else didn't want it; it is something to be thrown away. How can time-precious, priceless, unreplenishable-especially instructional time, be given away? I decided to consult the dictionary for direction. I felt sure the phrase "free time" would be followed by a definition explaining it as "wasteful and unnecessary." Unfortunately, The American Heritage Dictionary (1991 [1982], p. 531) I consulted didn't even have the phrase as an entry. I scanned the page to find the definition of "free," and surprisingly, I was encouraged by what I read: "not controlled by obligation or the will of another," and "not affected or restricted by a given condition or circumstance." These definitions instilled in me a new emotion - a sense of independence and peace associated with the notion of having unobligated and unrestricted free time. As many other teachers may also experience, I often feel resentment teaching what someone else says I must teach, instead of teaching what inspires me and will hopefully inspire my students. The "one size fits all" state mandated curriculum was not the best plan for everyone. Searching for another metaphor, I finally saw these snippets of free time not as leftovers but as a full meal. This meal would be one I could plan according to my own menu and flavor it with the spices of love and enthusiasm often missing from the prepackaged, preservative filled, frozen dinner lessons the state department serves. I could actually be a teacher, making decisions based on my own knowledge of my own students (personally, academically, emotionally, etc.) and based on the relationships we have built with each 
other. I felt eager yet relaxed knowing this time would be "free time" for teacher and student to learn from and with each other.

\section{Free time $=$ Experimentation}

As free time approached this particular year, I decided to experiment with my seventh grade classes. Since I was supervising a student teacher from the local university this semester, I divided the students into two groups according to their interests, love of reading, regular class participation, personality, etc. I knew teaching two classes inside one classroom would be difficult, so I decided to take my group of students outside. We dragged desks outside each day to have class, while the other students stayed indoors to read the novel Holes by Louis Sachar with the student teacher. The students and I formed a circle in order to better see each other and to share our thoughts and ideas as a group of equally interested participants. We sat on the sidewalk, under the canopy outside my classroom door: I was close enough to monitor the student teacher and her students but distanced enough so my class didn't interrupt hers. Being outside could have been a distraction for my class, since we were facing the parking lot and the street, but the disruptions were minimal. Even the occasional grass cutting and trains passing were minor interruptions-nothing problematic. Not only did we experience a new learning environment, but we also studied a new genre of literature.

I decided to revisit a novel I hadn't taught in a couple years-Sonya Sones's first poetic novel, Stop Pretending: What Happened When My Big Sister Went Crazy. I was introduced to poetic novels by Newberry Award Winning author, Richard Peck, who was teaching a class through the School of Library and Information Science at Louisiana State University one summer. Ann Angel (2004, p. 101) explains the attractiveness of the genre: "While some of these novels might initially attract some teens because the books appear easy to consume, with only a few words on the page and lots of white space, teens discover they enjoy poetry's stark, often unsentimental, yet provocative ways of using imagery and metaphor." She also adds, "The straightforward language about contemporary issues is what makes these works accessible to the most reluctant readers" (p. 102). This seventh grade group of students was a gathering of rather mature boys and girls. They were grade level aged (11-12 years old), but they had an awareness and wisdom unlike others groups of seventh graders. They were the perfect choice to experiment with "outside the box" thinking, and I hoped they would enjoy the novel I chose.

Stop Pretending is a collection of poems that creates a novel, a very Rich resource for "Crafting an Experience" (which is the title of one of Dr. William Doll's (n.p.) papers, which I will discuss later.) Using Angel (2004) as a text, I was able to build on the students' prior knowledge of poetic devices and literary terms and techniques such as: imagery, contrast, rhythm, alliteration, characterization, simile cataloging, repetition, economy, metaphor, pun, parallel structure, personification, hyperbole, symbolism, etc. This genre lends itself as a vehicle for carrying students' thoughts further. Angel quotes Ron Koertge from her email interview, who states: “...the language of poetry-the 
metaphor, simile, repetition-serves to challenge the young adult mind to make connections in more astounding ways" (p. 104). Not only did the students and I discuss writing techniques, but we were also able to discuss real world issues and themes such as bipolar disorder/ manic depression, symptoms and treatments of mental illness, poetic novels as a genre, semi-autobiographical literature, sisters, friendships, emotions, and even religious customs. Many of the students made connections to their own life stories. They talked about their own friendships. They shared personal fears. They even wondered about their own family members who exhibited bipolar tendencies. We even discussed Mrs. McC. (name changed), a retired teacher and now substitute the students see on our campus often, who was diagnosed as bi-polar. She is very public with her illness and urges students to realize people who have mental illnesses can still live successful lives. With all these benefits in mind, I felt confident in my choice of novel.

\section{Free time $=$ Freedom}

The planning for this unit brought with it a sense of freedom. I think back on what Alfred Crosby (2007 [1997], p. 230) refers to when he quotes Eviatar Zerubvel's description of modern culture: "precise, punctual, calculable, standard, bureaucratic, rigid, invariant, finely coordinated, and routine." This free time allowed me the opportunity to step back and away from these descriptions. I didn't have to be precise in my planning, or punctual to meet any deadlines. My assessments didn't have to be calculable by numbers; my observations determined student learning. There was no bureaucracy dictating my planning. While we still followed the routine of school bells and schedules, we created an alternative routine and fashioned our own learning environment. In planning the time frame for our novel unit, I had the freedom to determine the time necessary to finish reading the novel, and I built in extra time for discussion and reflection. I expected to finish the novel and discussions by the end of two weeks, but I didn't micromanage minute by minute what we would be thinking at every moment, like most lesson plans require. I decided ahead of time that we would pace ourselves, but allow the novel to guide us. In this, I am reminded of Martin Heidegger (2002, [1972, 1969], p. 66) when he suggests that the, "phenomenon itself, in the present case the opening, sets us the task of learning from it while questioning it, that is, of letting it say something to us" (emphasis added). The novel spoke to us, and we listened to it, and we listened to each other. This is how "learning," not "instruction" happened.

I didn't design or even plan for formal testing during this unit. I wanted to maintain a sense of freedom in which the students felt liberated enough to relax and reflect on the information discussed, instead of spending every second of time taking notes and worrying about memorizing information to regurgitate on a test. The way we spent our free time made a difference in the way students perceived their work. As we read the first few poems of the novel, the students began to feel the rhythm and flow of the poems. By reading aloud, I modeled proper oral reading habits (pausing, inflection), and by asking questions after each poem, I modeled thoughtful questioning habits. Before 
we were halfway through the book, students began responding quickly and delivering, without prompting, answers to questions I didn't even ask. For example, after we finished reading the title poem "Stop Pretending," and before I could catch my breath, a couple of students chimed in unison that there was repetition in the poem. I was amazed at how closely the students paid attention to the readings. Students even found examples of devices and techniques I didn't intend to point out. For example, one student noticed alliteration where I had overlooked it. Another student noticed a pun. Learning was evident, and no formal assessments had occurred.

By observing the students and the level of their responses, I was able to gather more information about their learning than I would have gathered from a pencil and paper test. I was able to see them as enthusiastic learners who wanted to participate in conversation with classmates with whom they usually never spoke. Since I was dealing with junior high students who need to be held accountable for their learning, and because I work for a bureaucracy that demands I assign at least one numerical measurement for each student's intellectual growth each week throughout the school year (sarcasm intentional), I felt obligated to assign some paper and pencil grades, but these, too, were non-traditional.

The first assignment given required the students to write summaries for poems read in the novel. This activity allowed me to evaluate how well the students comprehended each poem, while also giving the students a guide for reflection when we held discussions comparing and contrasting poems. Another assignment was dialogue journaling. When dialogue journaling, students wrote in their journals their opinions about a given topic related to the novel. Once they finished their comments, they ended each entry with a question. I chose a number, and the students were instructed to rotate their journals around the circle to another classmate who was many seats away. They read each other's thoughts, responded to what they read in the journal, and answered the question at the end of the entry. When partners swapped journals, the class discussion continued. This assignment not only encouraged students to speak to each other on a personal level but also offered them the chance to take part in their favorite pastime-writing notes. Because journaling should imitate conversation, I assured the students I would not grade them on the way they wrote in their journals. I anticipated they would write using the same tone and inaccuracies with which they spoke to each other and wrote in their notes, and I wanted them to write freely. I was more interested in their thinking than in their writing. The questions the students asked each other covered more areas than I could imagine. As Crosby (2007 [1997], p. 12) points out: "We need for purposes of comparison examples of another way of thinking." Through dialogue journaling, the students were able to become conscious of their classmates' opinions and thoughts. They were able to compare their initial thoughts to those of their classmates. Sometimes these comparisons resulted in students questioning themselves. These moments are important moments for students who are becoming old enough to begin making decisions about the world around them. They need to question the ideas around them, and these activities generated conversations that afforded them the opportunity for reflection. A sense of community was established by sharing. By 
presenting our initial reactions, thoughts and questions to each other in the dialogue journals and through class discussions, everyone participated in what Jayne Fleener (2002, p. 157) refers to as a "communication rich learning organization." I required the students pass the journals back and forth about three to four times in order for them to finish their conversations. I later read these dialogues and discovered how the students helped answer each other's questions and how they related to each other and the literature. A couple of boys tried to understand the complications of girlhood: "I don't understand this junk. First she says she's happy, then she's sad. Girlz are stupid. Am I missing something?" "No dude...their dum...." A pair of girls identified with the protagonist when they wrote, "I sooo feel like her. I totally loved the poem Molly, Kate and Me. I can't beleive her friends did her like that. What about you?" "Oh...yeah. I would still want them to get hit by a truck tho..." I watched as the students connected to the story characters and to each other. I graded students on their participation, journals and summaries. Education seems to be structured to foster instruction and assessment and not learning--what a misfortune. The time restrictions created by the deadlines designed to assess students' learning are real hindrances to the teaching and learning process--how ironic. I tried to break away not only from time restraints but also physical restraints.

\section{Free time $=\mathrm{New}$}

The whole idea of having class outside was a new and inviting experience for my students. In a survey given after the unit was complete, I asked my students to express how they felt about having class outside, and $100 \%$ of them responded positively. They described having class inside as "caged, trapped, and stuffy" and having class outside as "free, peaceful, and relaxed." One student wrote, "I like the outside classroom better because I feel free, like I'm not really in school, but I'm still learning - it's great!" What irony to hear these students use the word "free" to describe this learning period they had no idea had been labeled as "free time." When students feel free and have fun, one often assumes no instruction can take place and certainly no learning can result. So, why attempt something new? Possibly to open students' minds, to challenge their ideas, to have thoughtful conversation-aren't these the reasons many of us became teachers? Creating an atmosphere of trust and security also encourages students to feel free enough to let down their guards and open their minds to the thoughts of others.

Most of my students have always lived together in the town's small community. Many have known each other since kindergarten and others even before then. My challenge was to have these students see each other in a new light. I'm not sure when or how it happened, but for many of them, the light bulb lit up. In response to the survey questions, "What did you learn about yourself or your classmates, and how did you feel about our outside classes," I received these comments, "... after sitting together for so long my relationships have grown with some. I've grown to be nicer to people around me," "I found out people are smarter than they look...," "Yes, I have grown closer to everybody including Mrs. Stogner." Another student wrote about how he had been in 
this local school system since kindergarten and had never grown so close to his classmates in such a short period of time. Comments like these make me proud to be a teacher. Not only was I excited to listen to my students as they proved they really were learning about literature, poetry, characterization, etc., but I was also thrilled to hear them as they communicated with each other through meaningful discussion. They were able to take ownership of their learning because it was authentic.

\section{Free time $=$ Best things}

This experience has granted me the fortunate opportunity to bond with my students. As I began this particular school year, still bitter about being ousted from my high school nest and into the junior high nest, I somehow found myself growing to love these baby birds no matter how hard I tried to fight giving in. When we finished our classes outside, I asked the students if they realized how the structure of our class setting would be considered non-traditional because we were outside, not sitting in rows, and without a teacher towering over them like a dictator. In return, I heard comments such as, "I feel that when the teacher is sitting with us that she is the same as us and it shows me that she's just like us even though we still have respect for her," "I prefer the nontraditional setting over the traditional setting because this setting is less intimidating," "I think it's better for the teacher to be sitting with us in a circle because were on the same level and we can all talk \& discuss things as a class \& it's different cuz most teachers don't do that." They respected me not only because I was the authority figure, the leader, or the role model, but also because they knew I genuinely cared about their well-being. They knew they could trust and rely on me. Because of this connection, they felt free to express themselves without fear of judgment, criticism, embarrassment, or negativity. Fleener (2002, p. 156) suggests we "[e]ncourage: risk taking, creativity, multiple perspectives and approaches to problems, and learning." Too often, teachers are unable to take the risk and loosen the reign they have on their students. In order to accomplish this task, teachers must realize the "preoccupation with order, stability and consistency in all time frames damages management's creativity and ability to cope with the unknowable" (p. 157). The liberation of this free time allowed for this necessary encouragement. The students knew I was honest with them, and they felt secure knowing I would always try to lead them in their journey for creativity, judgment, information and understanding.

This time spent "outside the box" was a truly unique experience. As Dr. Doll (n.p., p.2) concludes his paper, "Crafting an Experience," he explains

Crafting as experience, then, is something each person must do individually, but as teachers we can help. We can encourage students to 'plunge into' subject matter, to see, feel, experience its aesthetic qualities-to explore the spirit of the subject at hand, as it were. And, in this process, as the experience begins to 'overwhelm them,' the students need to summon their own creative energy and thus help direct the experience to 'its own end,' thereby crafting an experience-unique yet universal. 
Our crafted experience occurred exactly as Dr. Doll describes it. As we plunged into the novel together, we shared moments together that challenged us intellectually and emotionally. This experience is one example of the limitless possibilities that exists for teachers and students.

Looking back at this time spent together with my students and trying to relate it to some of the concepts I studied recently in my post graduate class "Bending Time," I have become aware of the differences in time: inner, outer, linear, circular, situational, historical/ chronological, emotional, developmental, etc. The idea revealed itself to me one day: With this experiment in my seventh grade classes, I was actually experiencing another type of time-free time. We experienced academic learning, but we were also united. Fielding and Pearson (1994, p. 65) argue teachers should realize thinking comprehension will not increase by giving worksheet after worksheet as class assignments. They should spend less time teaching to their students: Teachers should spend more time reading with their students. The authors encourage teachers to meet the following three goals of reading instruction: " 1 . Changing teacher-student interaction patterns, 2. Accepting interpretations and reactions, and 3. Embedding strategy instruction in text reading." I sat in a circle with my students. I encouraged and listened to their thoughts and ideas. I sneaked examinations of the literary devices and techniques into the daily conversations. I informally observed student growth. Without even realizing what I had done, I had met these goals.

About three weeks after the outside classes concluded, I gave my students one more question. I asked: "If I had to write a paper about time and about what we did outside, what should I be sure to include in my paper?" I received the following responses: "I think you should write about the friendships that were created in that time," "the relationship between teacher:student and student:student," "Time is ageless," and my favorite, "Time is a matter of what you accomplish not minutes, hours, or days." I couldn't have said it better myself.

\section{References}

The American heritage dictionary second college edition. (1991). Boston: Houghton Mifflin Company.

Angel, A. M. (2004). Striking pensively, beating playfully: The power of poetic novels. English Journal 93(3):101-104.

Crosby, A. W. (2007). The measure of reality: Quantification and Western society, 1250- 1600. Cambridge: Cambridge University Press. (Original publication, 1997).

Doll, W. E. (n.p.) Crafting an experience. Retrieved January 28, 2009 from http://www.lsu.edu/faculty/wdoll/Papers/HTML/crafting_an_experience.htm

Fielding, L. G. \& Pearson, D. P. (1994). Reading comprehension: What works. Educational Leadership (51)5: 62-68.

Fleener, M. J. (2002). Curriculum dynamics: recreating heart. New York: Peter Lang.

Heidegger, M.. (2002). On Time and Being. Chicago: The University of Chicago Press. (Original publication, 1969, German; 1972, English).

\section{Acknowledgments}

This paper was previously presented at Curriculum Camp, a conference sponsored by the LSU College of Education and the Curriculum Theory Project, in Loranger, Louisiana in February 2009. 


\begin{abstract}
About the Author
E. Yvette Stogner is currently a doctoral student in the department of Educational Theory, Policy, and Practice at Louisiana State University in Baton Rouge, Louisiana. She also received her Bachelor of Science in Secondary English Education, Master of Library and Information Science, and Education Specialist degrees from LSU. She is a National Board for Professional Teaching Standards certified teacher, a teacher consultant with the Southeastern Louisiana Writing Project, and a certified student teacher supervisor. She has 17 years of experience teaching English Language Arts in grade levels 6 through 12. Most importantly, she enjoys spending time with her husband and two sons. Her email address is estogn1@lsu.edu
\end{abstract}

(C) Copyright 2010. The author, E. YVETTE STOGNER, assigns to the University of Alberta and other educational and non-profit institutions a non-exclusive license to use this document for personal use and in courses of instruction provided that the article is used in full and this copyright statement is reproduced. The author also grants a non-exclusive license to the University of Alberta to publish this document in full on the World Wide Web, and for the document to be published on mirrors on the World Wide Web. Any other usage is prohibited without the express permission of the author. 